\title{
On the Development of Literary Criticism in America after World War I
}

\author{
Chang-fa ZHENG \\ Department of Foreign Languages, Henan University of Animal Husbandry and \\ Economy, Zhengzhou, China
}

22456745@163.com

Keywords: Literature, Literary criticism, World War I, America.

\begin{abstract}
In the United States such critics as John Crowe Ransom, Allen Tate, Robert Penn Warren, and Cleanth Brooks agreed with Eliot that literary criticism should be a largely autonomous endeavor, distinct from biography, psychology, philosophy, and other disciplines. Brooks described this critical approach as "formalist" because it was centered on a close reading and an analysis of the elements-metaphor, imagery, symbolism, and so forth - of a poem or other piece of literature and not on its cultural context. The emphasis of this approach was well tailored to the complexity of Modernist literature, particularly poetry, which seemed to require literary critics to explain the work to the reader.
\end{abstract}

\section{Introduction}

Many of those who contributed to the development of literary criticism in America after World War I did not restrict themselves to literature but ranged more broadly as cultural critics, delving into considerations of society, politics, history, language, philosophy, and other arts. The period after the war was a time of reevaluation, and a general dissatisfaction with post-World War I American culture is evident in Civilization in the United States: An Inquiry by Thirty Americans (1922), edited by Harold E. Stearns, which includes his essay "The Intellectual Life," as well as H. L. Mencken's "Politics," Conrad Aiken's "Poetry," Ring Lardner's "Sport and Play," George Jean Nathan's "The Theatre," and Lewis Mumford's "The City." Some critics were considering fundamental questions about the purpose of literature, especially as the Great Depression shook society to its foundations. Marxist critics such as Mike Gold and Granville Hicks were trying to define what "proletarian literature" should become. The question of the purpose of literature was also considered by African American writers, as when Zora Neale Hurston's Their Eyes Were Watching God was attacked by Richard Wright for its depiction of African American folk culture. At the same time that independent critics such as Mencken, Mumford, Kenneth Burke, and Edmund Wilson were examining the relationship of literature to culture, a new and narrower focus on the work itself, which came to be known as New Criticism, was attracting adherents.

\section{Henry Louis (H. L.) Mencken the Most Influential Critic after World War I}

The most influential critic of contemporary literature after the war and through the 1920s was Henry Louis (H. L.) Mencken. Although his formal education ended with his graduation from high school, Mencken distinguished himself as a journalist, philologist, political commentator, and literary critic and came to be regarded as the country's greatest man of letters. In his newspaper columns for The Baltimore Sun he wrote for what he called the "civilized minority," satirizing everything from the 
hysteria surrounding World War I and the resurgence of the $\mathrm{Ku}$ Klux Klan to the Scopes "Monkey" Trial in Tennessee and the residual puritanism he believed infected American life. In all of his writing Mencken enjoyed "stirring up the animals." Mencken began to make his name as a literary critic before World War I. His early books include George Bernard Shaw: His Plays (1905) and The Philosophy of Friedrich Nietzsche (1908), the first studies on these authors to be published in America. He also edited and wrote introductions for Henrik Ibsen's A Doll's House and Little Eyolf in 1909 and was an early champion of the work of Joseph Conrad. In 1908 Mencken began to review books for The Smart Set: A Magazine of Cleverness, which he edited with George Jean Nathan from 1914 to 1923. From November 1908 to December 1923 he wrote 182 monthly articles on all manner of books, American and foreign-some 2,000 in all. Although for most of his years as a reviewer Mencken generally regarded American literature as inferior to European literature - an argument he makes in his 1920 essay "The National Letters" - he had begun to see signs of hope for advancement when he wrote his last essay for The Smart Set. In 1923 Mencken and Nathan left that magazine to found The American Mercury, which they edited together for two years before Mencken became the sole editor from 1925 to 1933. At The Smart Set Mencken and Nathan promoted Realism in fiction and drama, publishing work by Eugene O'Neill, Dorothy Parker, Theodore Dreiser, and Willa Cather; the first commercial story by F. Scott Fitzgerald; and the first publication in the United States by James Joyce. Authors whose work appeared in The American Mercury included Dreiser, Sinclair Lewis, Sherwood Anderson, William Faulkner, and Carl Sandburg. A much less combative literary journalist, Henry Seidel Canby, began his professional career as a professor of English at Yale University. He served as an assistant editor at the Yale Review from 1911 until becoming the editor of the Literary Review, a weekly supplement to the New York Evening Post, in 1920; in 1924 he founded The Saturday Review of Literature, which he edited until 1936. As the guiding hand of what became the most influential literary weekly in the United States and as the first chairman of the editorial board for the Book-of-the-Month Club, Canby exercised enormous influence on the American reading public. He was criticized both as too much of an elitist and as too much of a panderer to bourgeois tastes. Malcolm Cowley's parody in the journal Aesthete 1925-"Editor Outlines Middle Course between Heaven and Hell. Solution Deemed Acceptable to Both Modernists and Fundamentalists"-suggests Canby's difficult position in negotiating between his audiences while certainly overstating his success in pleasing everyone. Canby strove to broaden as well as deepen the discussion of American literature, writing in his American Memoir (1947) of "the Jeffersonian belief in the necessity of education for a successful democracy" that animated his career: "I wanted to go in for adult education in the value of books - all kinds of books, foreign as well as native, but particularly the current books of our own country. I wished to make criticism first of all a teaching job, backed up by explorations and estimates of new ideas."

\section{The New Criticism in the United States in the 1940s and 1950s}

The New Criticism, which became the dominant school of literary criticism in the United States in the 1940s and 1950s, was influenced by Eliot, the formidable American poet living in England who was also one of the most important literary theorists of the twentieth century. In The Sacred Wood: Essays on Poetry and Criticism (1920), which includes book reviews as well as several longer essays, Eliot 
discusses the work of Algernon Swinburne, William Blake, Dante, Philip Massinger, Ben Jonson, and William Shakespeare, and defines terms and concepts that have entered into critical discourse. In his essay "Hamlet and His Problems," for example, Eliot provides a famous formulation for how poetry communicates emotion to the reader or listener: "The only way of expressing emotion in the form of art is by finding an 'objective correlative'; in other words, a set of objects, a situation, a chain of events which shall be the formula of that particular emotion; such that when the external facts, which must terminate in sensory experience, are given, the emotion is immediately evoked." As this rather abstract description suggests, Eliot was interested in moving beyond "aesthetic" or "impressionistic" criticism that depended on the interpretations of "a sensitive and cultivated mind" toward a surer, less subjective footing for criticism. In the preface to the 1928 edition of The Sacred Wood he articulated the idea that unified his collection of essays: "It is an artificial simplification, and to be taken only with caution, when I say that the problem appearing in these essays, which gives them what coherence they have, is the problem of the integrity of poetry, with the repeated assertion that when we are considering poetry we must consider it primarily as poetry and not another thing."

In the United States such critics as John Crowe Ransom, Allen Tate, Robert Penn Warren, and Cleanth Brooks agreed with Eliot that literary criticism should be a largely autonomous endeavor, distinct from biography, psychology, philosophy, and other disciplines. Brooks described this critical approach as "formalist" because it was centered on a close reading and an analysis of the elements-metaphor, imagery, symbolism, and so forth - of a poem or other piece of literature and not on its cultural context. The emphasis of this approach was well tailored to the complexity of Modernist literature, particularly poetry, which seemed to require literary critics to explain the work to the reader. Brooks and Warren spread the methodology of New Criticism through their textbooks Understanding Poetry (1938) and Understanding Fiction (1943), in which they stressed that a great work of literature has multiple meanings. While not denying the importance of social, moral, cultural, or religious contexts in the study of literature, they believed that such considerations were subordinate to the study of the organic nature of a poem or novel: the way the elements combine to produce a living work of art.

To indulge in gross oversimplification, in the first half of the twentieth century the focus of literary criticism generally shifted from the author's biography and supposed intention in writing a work - an approach that might be suggested by the question "What did the author mean to communicate?"- to the formal aspects of the literary object in the New Criticism, an approach perhaps best suggested by the question "How does the text work?" After the crest of the influence of the New Critics in the post-World War II years, the focus shifted again in the latter half of the twentieth century, toward the critic and the meaning he or she could find in - or make out of - the literature examined: "What is the significance of this literary work?" A variety of reader- or critic-oriented theories - from psychoanalytic, feminist, and reader-response to deconstruction, new historicist, and cultural or Marxist approaches - have flourished since the 1960s.

\section{The Change of Literary Fashions and Opinions}

Contemporary judgments of the most important or the best writers are often reversed by later generations. While Eugene O'Neill was recognized as a towering figure in the American theater by his contemporaries — a judgment time has not changed — many 
of the novelists and poets who were regarded as major figures in their own time have faded from memory, and writers who were ignored then have come to be regarded as significant only in retrospect. In the 1920s, for example, many critics might have chosen Joseph Hergesheimer - a largely forgotten novelist whose name appears only a few times in this volume - as among the first rank of American writers. And many of the novelists who are now regarded as major figures of the interwar years-F. Scott Fitzgerald, William Faulkner, Zora Neale Hurston, to name only a few-were, for different reasons, undervalued by their contemporaries. In the twenty-first century readers and critics have a rich variety of ways to approach literary texts. As Lois Tyson suggests in her readable introduction, Critical Theory Today (1998), "theory can help us learn to see ourselves and our world in valuable new ways"; but no single critical approach can exhaust the meaning of a literary text, particularly when that text is an enduring work of art. The greatest of the novels, stories, plays, and poems of the interwar years continue to speak to us as readers and to provide a not-so-distant mirror in which to contemplate our reflection.

The early post-Civil War promise of equal protection and increased civil rights for African Americans was eviscerated by decades of Jim Crow laws, culminating in the 1896 Supreme Court decision in Plessy v. Ferguson that sanctioned legalized racial segregation. This "separate but equal" doctrine-which was used to make African Americans second-class citizens-remained America's governing policy until the 1954 decision in Brown v. Board of Education. Spanning the years of the two world wars, African American writers, working within an already complex formative literary tradition, continued to respond to the daunting inequities of their times in voices that were defiant and conciliatory, political and personal, measured, celebratory, and transcendent. The works of the Harlem Renaissance, varied and numerous, reflect the suffering provoked by the lingering status quo, pose disparate social and moral solutions to the cruelties of systemic injustice, and demonstrate a historically aware, conscious movement toward aesthetic vitality and freedom. Social reform leaders such as Frederick Douglass (1818-1895) and Progressive Era writer Frances Ellen Watkins Harper (1825-1911), who came of age during the Civil War and its aftermath, established protocols for public action and autobiographical frankness that served as models for a new politically vigilant generation of artists and activists, many of whom joined the burgeoning black populations that reshaped urban areas during the years of the Great Migration (roughly 1910-1940 or beyond). The uptown section of New York City called Harlem became an artists' mecca, a vibrant, thrilling "race capital" in the words of philosopher Alain Locke. As rapturously expressed by James Weldon Johnson in his essay, "Harlem: The Culture Capital," in the "New Scene" section of Locke's landmark 1925 anthology, The New Negro, Harlem was a "city within a city, the greatest Negro city in the world."

\section{Conclusion}

The cultural renaissance of the 1920s and 1930s was predicated on the work of artists and activists who broke new ground in previous generations. The last decade of the nineteenth century through to America's entrance into World War I (1917) is often characterized as the Progressive Era when social reform movements helped set new standards for labor, education, public safety, and women's rights. Black writers were acutely concerned with problems of "uplifting" the race, with exposing the exclusionary hypocrisy of the ethical ideals of the supposedly United States, and with offering platforms for integration or rebellion. Though writers, intent on offering 
correctives to derogatory, degrading images of black life presented to the white reading public, disagreed on what constituted appropriate subjects, language, politics, and the fundamental relevance of color was an inescapable constant in the literary mix.

\section{References}

[1] Charles Davis and Michel Fabre, Richard Wright, a Primary Bibliography (Boston:

G. K. Hall, 1982).

[2] Keneth Kinnamon, A Richard Wright Bibliography: Fifty Years of Criticism and Commentary, 1933-1982 (New York: Greenwood Press, 1988).

[3] Kinnamon, Richard Wright: An Annotated Bibliography of Criticism and Commentary, 1983-2003 (Jefferson, N.C.: McFarland, 2006). 